\title{
Vegetable and Flower Production in the Central Highlands of Vietnam: Current Status and Perspective Strategies
}

\author{
Vu Quynh Hoa ${ }^{1}$, Ngo Minh $\mathrm{Hai}^{2}$, Nguyen Duc Huy ${ }^{1}$, Tran Van \\ Quang ${ }^{1}$, Ninh Thi Phip', Bui The Khuynh', Bui Ngoc Tan'1, Vu \\ Thanh Hai ${ }^{1}$, Nguyen Duc Khanh ${ }^{1}$, Nguyen Anh Duc ${ }^{1}$, Pham \\ Tuan Anh ${ }^{1}$, Nguyen Van Loc ${ }^{1} \&$ Tran Duc Vien ${ }^{3}$ \\ ${ }^{1}$ Faculty of Agronomy, Vietnam National University of Agriculture , Hanoi 131000, \\ Vietnam \\ ${ }^{2}$ Faculty of Economics and Rural Development, Vietnam National University of \\ Agriculture , Hanoi 131000, Vietnam \\ ${ }^{3}$ Chairman of University Council, Vietnam National University of Agriculture , Hanoi \\ 131000 , Vietnam
}

\begin{abstract}
Despite significant contributions of vegetable and flower production to the improvement of the livelihoods of household producers in the Central Highlands of Vietnam, several challenges facing the development of this sector require a general evaluation. This study aimed at assessing the current situation and economic efficiency of flowers and vegetables and analyzing the application of production techniques on the cultivation of these crops. Based on secondary data sources combined with a primary survey of 144 vegetable farmers and 74 flower growers in all five provinces (Lam Dong, Dak Lak, Dak Nong, Kon Tum, and Gia Lai) of the area in 2018, descriptive statistics and economic values were applied to provide an overview of the development of vegetable and flower production of the region. Findings showed that there were large differences in yields and economic efficiencies of vegetables and flowers among the five provinces of the Central Highlands. Accordingly, the yields and economic efficiencies of vegetables and flowers in Lam Dong were two to five times higher than those in other provinces (Dak Lak, Dak Nong, Kon Tum, and Gia Lai). In addition, the applications of technological advances in vegetable and flower production remained limited. Major challenges for flower and vegetable development included the lack of irrigation water, weak capabilities of building flower and vegetable brands, and limitations in market access. Solutions to improve production technology implications, develop brands of high-quality products, and raise the ability to access market for all vegetable and flower stakeholders are highly recommended.
\end{abstract}

\section{Keywords}

Vegetables, flowers, Central Highlands, crop production, Vietnam 


\section{Introduction}

The vegetable and flower sectors have been increasingly developed in Vietnam for recent years. Specifically, the harvested area of vegetables of the country reached 0.84 million ha in 2017, making vegetables one of the biggest crops in Vietnam (ranked behind paddy rice and maize in terms of production areas) (FAOSTAT, 2019). The main areas for vegetable production are Hanoi city, Ho Chi Minh city, and Lam Dong province (Ngo et al., 2019). The average yield of vegetables was around 17 tons ha $^{-1}$ in 2017 (FAOSTAT, 2019). However, the quantity of exported vegetables was only 180 thousand tons, accounting for $1.4 \%$ of the total vegetable production, with an export value of 200 million USD in 2016 (Ngo et al., 2019). The main problems in vegetable production and business are food safety (i.e., overuse of chemical pesticides) in the domestic market and small export values (Ngo et al., 2019; Van Hoi et al., 2009; World Bank, 2017). Meanwhile, the data about the flower is quite scarce. It was estimated that there were 22.6 thousand ha of flowers in Vietnam in 2014, which was mainly concentrated on Da Lat city (Lam Dong province), Hanoi and Sapa - Lao Cai province (the North), and Ho Chi Minh city (the South) of Vietnam (Ha Anh, 2016; Lamdongdost, 2016). Of these provinces or cities, flower production in Da Lat city accounted for $40 \%$ of the total area and $50 \%$ of the total cut flower quantity nationwide. Similar to the vegetable sector, flowers for the export market only attained a minor value of 100 million USD in 2013 (Lamdongdost, 2016). Some problems hindering the development of flowers were mentioned (without clear evidence) in the newspapers such as fragmented production land, low-quality seeds of flowers, negative effects of climate changes, inadequate amount of investment, limitations in applying for technological advances in flower production, and lack of market demand forecasting (Ha Anh, 2016).

The Central Highlands has unique geographical characteristics. The region's topography is divided into three main subdivisions, including hilly (altitude 1000-2000m, with an area of 2.89 million ha, accounting for
$53 \%$ of the total area), plateau (altitude 100$800 \mathrm{~m}$, accounting for $36.5 \%$ of the total area), and alluvial valley/plain (accounting for $10.5 \%$ of the total area) (MPI, 2017). The Central Highlands (including 5 provinces, namely Kon Tum, Gia Lai, Dak Lak, Dak Nong, and Lam Dong) is considered to have great potentials and advantages in the land, minerals, and natural resources with diverse flora and fauna systems (Do et al., 2017; Prime Minister, 2012). Particularly, the area has fertile soil (mainly characterized by acrisols and ferralsols) and tropical monsoon climate (moderate and subtropical), which are suitable for developing a big commodity agriculture sector (Minh, 2017; Decision No. 936 of the Prime Minister, 2012). As a result, the Central Highlands is one of the biggest production areas for coffee, pepper, maize, cashew nut, flowers, and vegetables in Vietnam (Prime Minister, 2012). Among its provinces, Lam Dong becomes one of the biggest areas for vegetable and flower production in the country (Ngo et al., 2019). This is the fundamentals for building and developing major agricultural production in Vietnam (Decision No. 936 of the Prime Minister, 2012).

Agriculture industry still plays an important role in the economic development of the Central Highlands, accounting for $34.7 \%$ of the total GDP of the whole region by 2020 (Decision No. 936 of Prime Minister, 2012). The comprehensive transformation of agricultural structure in the Central Highlands to 2020 is oriented toward expanding high-value industrial crops such as vegetables, flowers, and fruits from low-productivity crops such as rice (Decision 936 of Prime Minister, 2012). Thus, short-term and most valuable crops such as vegetables and flowers have played an increasingly important role in improving the living standards of households as well as promoting economic growth of the Central Highlands' provinces.

For recent years, the Central Highlands has developed considerably as a result of great attention from the government through a huge investment in a series of state-level programs/projects (i.e., the Central Highlands Programs 1, 2, and 3). The annual economic growth rate reached a high level of $10 \%$ per year 
in a long time before the year 2016 although there was a decline to around 7.4\% in 2016 (Quang Huy, 2017). This contributed to improving the living standards of the people with a GDP per capita of around 40 million VND in 2016 and reducing the poverty rate to $15 \%$ (Ly, 2017). However, many challenges for the economic development of agriculture were mentioned in the reports of the Central Highlands Program 3. The key challenges hindering agriculture development included severe land degradation, negative impacts of industrial projects (i.e., bauxite mining) on the environment, and adverse effects of climate change (i.e., global warming) (Nguyen Khoi, 2015). Although research on vegetables and flowers has been conducted in the Central Highlands Program, these previous studies were only conducted in a typical province, Lam Dong province (see in Bui Quang Tuan, 2016), but have not reflected the current situation in the whole Central Highlands. While some previous works on drought, forest diversity, land-use change, or economic changes have been conducted in the Central Highlands (Bui Quang Tuan, 2016; CCAFS-SEA, 2016; Do et al., 2017; Thai, 2018), a general assessment of flower and vegetable development remains absent.

Therefore, our study aimed to provide an overview of the vegetable and flower development in all five provinces of the Central Highlands based on up-to-date data. The objectives of the study were: (i) introducing the general situation of vegetable and flower development in the Central Highlands; (ii) assessing the economic efficiency of vegetables and flowers at the surveyed households in the region; (iii) analyzing the current situation of applying scientific and technological advances in the production of flowers and vegetables; (iv) summarizing advantages, difficulties, and challenges for the development of vegetables and flowers in the area; and ( $\mathrm{v}$ ) proposing policy recommendations to promote the development of flower and vegetable industry in the Central Highlands.

\section{Methodology}

\section{Data collection}

Data were collected from the following main sources. First, data on the production and vegetable areas were the secondary data from the Statistical Yearbook of all five provinces (Dak Lak, Dak Nong, Gia Lai, Kon Tum, and Lam Dong) in the Central Highlands in the period of 2016-2018. Complementary data from socioeconomic reports and agricultural production reports of Plant Protection Bureaus (Plant Protection), provincial Departments of Agriculture and Rural Development of all these five provinces were used. Previous reports and research on the situation of agricultural development in the Central Highlands provinces were also gathered.

In addition, the primary data were collected from face-to-face interviews with farmers and indepth interviews with managers and technical staff at the five provinces in 2018. To collect data from vegetable growers, based on the statistical yearbook of five provinces, a sample of 40 questionnaires per province was distributed in Dak Lak, Dak Nong, Gia Lai, and Kon Tum provinces, while 60 questionnaires were delivered to vegetable farmers in Lam Dong province where vegetables are more popular than in the other provinces. After eliminating incomplete responses, the final sample sizes of Dak Lak, Dak Nong, Gia Lai, Kon Tum, and Lam Dong were 22, 20, 30, 22, and 50, respectively. Meanwhile, flower farmers were only surveyed in two key provinces, namely Lam Dong (60 samples) and Kon Tum (40 samples), because no data on flowers (i.e., area or quantity) in the three remaining provinces were reported in the statistical yearbooks. The final sample of flower growers were 26 and 48 in Lam Dong and Kon Tum, respectively, after removing invalid and uncompleted responses. In summary, a sample of 144 households growing vegetables in all five provinces and 74 households growing flowers in two key provinces (Lam Dong and Kon Tum) were used for the analysis. These data were analyzed to identify the economic and environmental efficiencies of flowers and vegetables in producer households. More 
importantly, the motivations and obstacles for the development of vegetables and flowers were also highlighted.

\section{Data analysis}

The statistical analyses such as comparative and descriptive statistics were used to reflect the current situation of production, fluctuations in yields, and values of vegetables and flowers.

Economic efficiency indicators for the crops were then measured as follows (MARD, 2009):

Value added $(\mathrm{VA})=$ Gross Output $(\mathrm{GO})-$ Intermediate Costs (IC)

Where GO = Product Quantity x Price

IC consists of costs for materials (i.e., seedings, fertilizers, and pesticides), labor costs, production costs (i.e., land cultivation, irrigation water, and plant protection), transportation costs, and interest payments from bank loans.

In addition, assessments of the current applications of technical measures and challenges were gathered and analyzed through descriptive and comparative statistics, which were presented scientifically via tables and graphs.

\section{Results}

\section{Overview of the development of vegetables and flowers in the Central Highlands}

The development of vegetables in general and safe vegetables in particular

The cultivated area of vegetables in five provinces of the Central Highlands was about 138,000 ha in 2018, an increase of $3.7 \%$ compared to that in 2016. In particular, the largest area belonged to Lam Dong province with over 63,000 ha in 2018 , accounting for $45 \%$ of the total cultivated area of the Central Highlands region. The second rank in terms of area is Dak Lak province, with 34,000 ha in 2018 . Regarding the total vegetable production, the Central Highlands provinces produced an average quantity of 2.5 to 2.8 million tons of vegetables each year. Of the total quantity, vegetable production in Lam Dong accounted for $75 \%$ of the total output of the Central Highlands. In terms of vegetable yield, Lam Dong also reached the highest figure (33 tons per ha in 2018), which was much higher than those of the remaining provinces of the region, 2.5 times higher than the figure of in Gia Lai and 5-6 times higher than the figure of Dak Lak or Dak Nong. The vegetable yield in Lam Dong province is also the biggest in the whole country. Details of the increase in vegetable area and productivity of Lam Dong province are presented in Figure 1. Accordingly, both the area and vegetable yield tended to increase steadily during the period from 2010 to 2018. Meanwhile, with a small yield of 5-7 tons per ha, Dak Lak and Dak Nong indicated either low technical efficiencies or unfavorable land characteristics for vegetable production.

Regarding the development of safe vegetables, there was a lack of comprehensive statistics of all Central Highlands provinces. In Lam Dong province, the largest vegetable production area in the Central Highlands, the proportion of VietGAP vegetables was only about $8 \%$ of the total vegetable quantity (Lam Dong Plant Protection Department, 2016). However, the province has also developed vegetable production based on high technology, accounting for about $28 \%$ of the vegetable area of the province.

\section{The current status of flowers production}

Currently, the official statistics on flowers were only available in Kon Tum and Lam Dong provinces, while Gia Lai and Dak Nong provinces only had data on the area without on the quantity and yields of flowers. Notably, there was also no statistical data on flowers in Dak Lak province. This may be due to the limited area of flowers grown in these provinces. Lam Dong province had the largest area of flowers in the Central Highlands, with over 8,200ha in 2018, while Kon Tum had only about 180 hectares (Table 2). The quantity of cut flowers in Lam Dong province reached nearly 2.8 billion stems, with a yield of over 330 thousand cut flower stems per ha. This yield was two times higher than that of Kon Tum. 
Table 1. Area, quantity, and yields of vegetables in the Central Highlands during 2016-2018

\begin{tabular}{cccccccccc}
\hline \multirow{2}{*}{ Provinces } & \multicolumn{3}{c}{ Area (thousand ha) } & \multicolumn{3}{c}{ Quantity (thousand tons) } & \multicolumn{3}{c}{ Yield (tons ha ${ }^{-1}$ ) } \\
\cline { 2 - 10 } & 2016 & 2017 & 2018 & 2016 & 2017 & 2018 & 2016 & 2017 & 2018 \\
\hline Dak Lak & 34.7 & 36.1 & 34.0 & 210.2 & 243.1 & 234.6 & 6.1 & 5.8 & 6.9 \\
Dak Nong & 11.4 & 11.9 & 12.4 & 74.4 & 77.6 & 60.8 & 6.5 & 6.5 & 4.9 \\
Gia Lai & 26.5 & 27.03 & 27.0 & 362.8 & 358.7 & 369.6 & 13.7 & 13.7 & 13.3 \\
Kon Tum & 2.5 & 2.63 & 2.7 & 28.3 & 29.6 & 30.9 & 11.2 & 13.4 & 11.5 \\
Lam Dong & 59.0 & 61.4 & 63.2 & $1,873.4$ & $1,980.6$ & $2,091.7$ & 31.8 & 32.4 & 33.1 \\
\hline Total & 134.2 & 139.1 & 139.2 & $2,548.7$ & 2,689 & $2,786.8$ & 26.10 & 26.6 & 27.3 \\
\hline
\end{tabular}

Source: Provincial Statistics Offices (Dak Lak, Dak Nong, Gia Lai, Kon Tum, and Lam Dong) in the Central Highlands (2018).

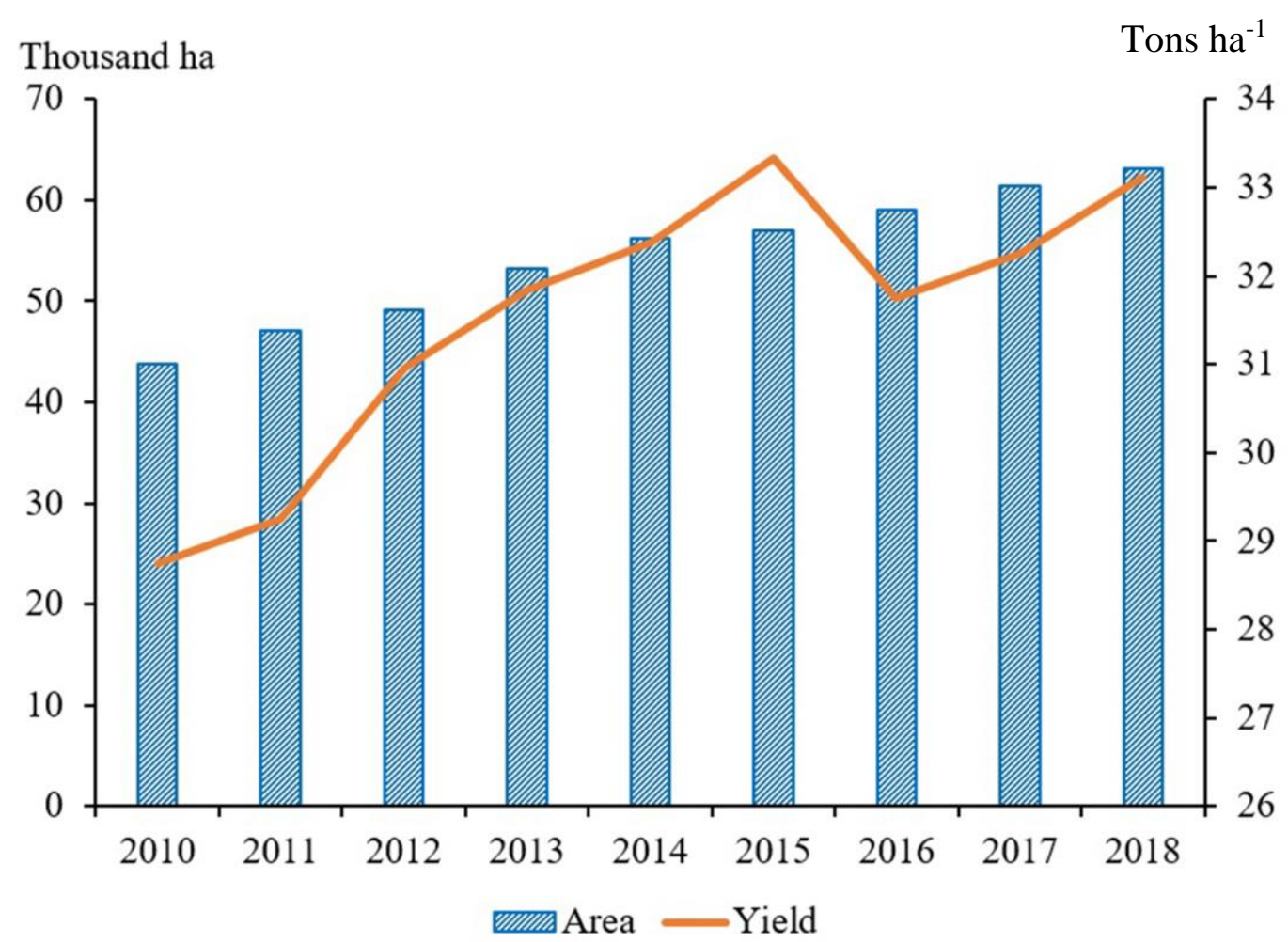

Figure 1. Area and yield of vegetables in Lam Dong province during 2010-2018 Source: Statistical Year Book of Lam Dong (2018)

Table 2. Area, quantity, and yield of cut flowers in the Central Highlands during 2016-2018

\begin{tabular}{|c|c|c|c|c|c|c|c|c|c|}
\hline \multirow[t]{2}{*}{ Provinces } & \multicolumn{3}{|c|}{ Area (ha) } & \multicolumn{3}{|c|}{$\begin{array}{c}\text { Quantity } \\
\text { (million stems) }\end{array}$} & \multicolumn{3}{|c|}{$\begin{array}{c}\text { Yield } \\
\text { (thousand stems ha-1) }\end{array}$} \\
\hline & 2016 & 2017 & 2018 & 2016 & 2017 & 2018 & 2016 & 2017 & 2018 \\
\hline Dak Lak & - & - & - & - & - & - & - & - & - \\
\hline Dak Nong & 68 & 54 & - & - & - & - & - & - & - \\
\hline Gia Lai & 157 & 183 & - & - & - & - & - & - & - \\
\hline Kon Tum & 147 & 150 & 181 & 24.1 & 18.6 & 23.7 & 164.1 & 123.7 & 147.1 \\
\hline Lam Dong & $7,908.9$ & $8,152.3$ & 8,283 & 2,504 & 2,726 & 2,789 & 317.9 & 334.3 & 336.7 \\
\hline
\end{tabular}

Source: Provincial Statistics Offices (Dak Lak, Dak Nong, Gia Lai, Kon Tum, and Lam Dong) in the Central Highlands (2018). 


\section{Businesses in vegetables and flowers}

Most vegetables and flowers were distributed to Ho Chi Minh city and neighboring provinces through local distributors and traders. A small percentage of vegetables and flowers were shipped to major cities in the North such as Hanoi and the Central Coast provinces. The quantity of these products for export was very small. For example, in Lam Dong province, only about $1 \%$ of such vegetables and $5 \%$ of cut flowers were exported to foreign countries such as Japan, Malaysia, Thailand, and Korea (Lam Dong Plant Protection Department, 2016; Lamdongtv, 2016).

\section{Economic efficiency of vegetables and flowers at the surveyed households in 2018}

\section{Economic efficiency of vegetables}

A variety of vegetables was grown by the farmers in the Central Highlands such as cabbages, tomatoes, carrots, potatoes, onions, and lettuce. However, the most diversity of vegetables were in Lam Dong province, where the soil and climate were favorable for growing various types of vegetables. In general, the vegetable producer households in Lam Dong province had the largest cultivated area, with an average of over $7,000 \mathrm{~m}^{2}$, followed by Gia Lai $\left(4,600 \mathrm{~m}^{2}\right)$, Dak Lak $\left(3,000 \mathrm{~m}^{2}\right)$, and the smallest was Kon Tum $\left(1,700 \mathrm{~m}^{2}\right)$. After covering expenses, the value-added received by each household in Lam Dong was 235 million VND, much higher than that of households in the other provinces (Table 3).

\section{Economic efficiency of flowers}

The statistics on the area, the yield, and the economic efficiency of flowers in Lam Dong and Kon Tum are presented in Table 4. As aforementioned, there were very few farmers growing flowers in the three remaining provinces of the Central Highlands. Thus, producer survey in these areas was not carried out. In Lam Dong, cut flowers were mainly planted in Da Lat city, Lac Duong, and Duc Trong districts. The types of flowers were quite varied, with carnations, roses, hydrangeas, lisianthus, chrysanthemums, and anthuriums, etc. In Kon Tum province, flowers were popularly grown in Kon Plong district with gladiolus, lilies, and chrysanthemums. In general, flower producers obtained high economic efficiency, especially in Lam Dong with over 500 million VND per household. However, flower production required a high initial investment of 90 million to 200 million VND, depending on whether the net/glasshouse systems were covered or not covered.

Applications of technological advances in production and negative impacts of diseases on the growth of vegetables and flowers

Applications of technological advances in vegetable and flower production

One of the important objectives of this study was to evaluate the applications and implementation of technical measures in vegetable and flower production in the surveyed households. The results I $n$ Table 5 indicate that

Table 3. Economic efficiency of vegetables of the surveyed households in 2008

\begin{tabular}{lcccccc}
\hline \multicolumn{1}{c}{ Indicators } & Units & Dak Lak & Dak Nong & Gia Lai & Kon Tum & Lam Dong \\
\hline Sample size & households & 22 & 20 & 30 & 22 & 50 \\
Average & $\mathrm{m}^{2}$ & 3,000 & 2,800 & 4,600 & 1,700 & 7,090 \\
area/household & tons & 2.5 & 2.2 & 5.8 & 2.0 & 23.1 \\
Quantity & million VND & 30 & 28 & 69 & 24 & 277 \\
Gross output & million VND & 12.5 & 13 & 19.0 & 7.5 & 42 \\
Intermediate costs & million VND & 27.5 & 15.0 & 50 & 16.5 & 235 \\
Value added & & & & &
\end{tabular}

Note: Because households grew a variety of vegetables with differences in crops, yields, and prices, specific criteria for each type of vegetables such as yield, selling price, and cost were not presented. 
Table 4. Economic efficiency of flowers of the surveyed households

\begin{tabular}{|c|c|c|c|}
\hline \multirow{2}{*}{ Indicators } & \multirow{2}{*}{ Units } & \multicolumn{2}{|c|}{ Provinces } \\
\hline & & Kon Tum & Lam Dong \\
\hline Sample size & households & 26 & 48 \\
\hline Average area per household & $m^{2}$ & 2100 & 2500 \\
\hline Quantity & thousand stems & 30 & 65 \\
\hline Gross output & million VND & 360 & 715 \\
\hline Intermediate costs & million VND & 130 & 200 \\
\hline Value added & million VND & 230 & 515 \\
\hline
\end{tabular}

Source: Fieldwork (2018)

Table 5. Applications of technical advances in vegetable and flower production

\begin{tabular}{|c|c|c|c|c|c|}
\hline \multirow[b]{2}{*}{ Techniques } & \multicolumn{5}{|c|}{ Provinces } \\
\hline & $\begin{array}{c}\text { Dak Lak } \\
(\%, \mathrm{n}=22)\end{array}$ & $\begin{array}{l}\text { Dak Nong } \\
(\%, n=20)\end{array}$ & $\begin{array}{c}\text { Gia Lai } \\
(\%, n=30)\end{array}$ & $\begin{array}{l}\text { Kon Tum } \\
(\%, n=22)\end{array}$ & $\begin{array}{l}\text { Lam Dong } \\
(\%, n=50)\end{array}$ \\
\hline \multicolumn{6}{|l|}{ Irrigation } \\
\hline + By hands & 33.3 & 100.0 & 46.5 & 88.9 & 4.5 \\
\hline + Spraying & 66.7 & 0.0 & 53.5 & 11.1 & 77.3 \\
\hline + Dripping & 0.0 & 0.0 & 0.0 & 0.0 & 18.2 \\
\hline \multicolumn{6}{|l|}{ Fertilizer application } \\
\hline + Broadcasting & 100.0 & 66.7 & 85.7 & 93.8 & 36.4 \\
\hline + Fertigation & 0.0 & 33.3 & 14.3 & 6.2 & 63.6 \\
\hline \multicolumn{6}{|l|}{ Flowering treatments } \\
\hline+ Yes & 0.0 & 0.0 & - & 0.0 & 35.0 \\
\hline+ No & 100.0 & 100.0 & - & 100.0 & 65.0 \\
\hline \multicolumn{6}{|l|}{ Breeding } \\
\hline+ Yes & 0.0 & 0.0 & 0.0 & 0.0 & 28.6 \\
\hline+ No & 100.0 & 100.0 & 100.0 & 100.0 & 71.4 \\
\hline \multicolumn{6}{|l|}{ Preservation after harvest } \\
\hline+ Yes & 0.0 & 0.0 & 0.0 & 0.0 & 21.0 \\
\hline+ No & 100.0 & 100.0 & 100.0 & 100.0 & 79.0 \\
\hline
\end{tabular}

Note: $n=$ sample size.

the techniques in watering and fertilizing in Lam Dong were much higher than in the remaining provinces. Only farmers in Lam Dong used drip irrigation, which allowed for the optimal usage of water and fertilizers thanks to the application close to crop roots. The percentage of farmers, who used spray/sprinkler irrigation to distribute water to larger areas easily, was also higher in Lam Dong than in the other provinces. Furthermore, the flowering induction in Lam Dong has been conducted mainly in supplementary light treatment. Product postharvest preservation was mostly carried out using carton boxes, only few big farms used 
cooling/cold storage.

Negative impacts of pests and diseases on the growth of vegetables and flowers

Harmful effects of pests and diseases on the growth of vegetables and flowers are presented in Table 6. It can be seen that the Central Highlands' producers faced leaf worms, stem, and fruit borers, which were common in all five provinces. However, the worse situation occurred in Dak Lak, Dak Nong, and Gia Lai provinces. While leaf and stem borers were also popular in Lam Dong, vegetable producers, however, considered them to be less severe. In addition, thrips, aphids, spiders, and aphids were also responsible for negative effects on crops. Regarding diseases, fungal, downy, and stem rot were also common in most of the provinces, but being more serious in Dak Lak and Dak Nong.

In this study, households were directly asked to indicate which factors played an important role in vegetable and flower production and consumption. The results in Figure 2 show that market factors (including prices and markets for the product) were ranked as the most important (57\% and 54\%). Other factors such as weather, investment level, and water resources had considerable effects on the production of vegetables and flowers because these crops were mainly grown outdoors based on natural conditions. Only few households had the capability to build net houses or greenhouses for vegetable/flower production. In addition, serious drought and lack of irrigation water were also the main obstacles in vegetable and flower production in the Central Highlands. Meanwhile, factors related to plant protection chemicals and farming practices were not considered as the main barriers to growing vegetables and flowers. The survey also showed that households did not face any difficulties in recognizing plant pests and diseases because these producers accumulated a lot of farming experiences for several years. Furthermore, the use of pesticides by producer households was mainly influenced by pesticide dealers, and the quality was guaranteed.

\section{Local government's supports and assistance}

The results showed that most producers only received technical assistance for flower and vegetable production (such as safe production) from the local government agencies and production training or technical consultation from the local businesses. In Lam Dong, some

Table 6. Harmful effects of pests and diseases on the growth of vegetables and flowers

\begin{tabular}{|c|c|c|c|c|c|}
\hline \multirow{2}{*}{ Types of harmful pests and diseases } & \multicolumn{5}{|c|}{ Levels of popularity and seriousness of pests/diseases } \\
\hline & Dak Lak & Dak Nong & Gia Lai & Kon Tum & Lam Dong \\
\hline \multicolumn{6}{|l|}{ Harmful pests } \\
\hline + Leaf worms, stem, and fruit borers & X3Y3 & X3Y3 & Х3Y3 & X3Y2 & $\mathrm{X} 3 \mathrm{Y} 1$ \\
\hline+ Thrips & X3Y3 & $\mathrm{X} 2 \mathrm{Y} 1$ & $\mathrm{X} 2 \mathrm{Y} 2$ & & $\mathrm{X} 1 \mathrm{Y} 1$ \\
\hline + Fruit flies & & & & & $\mathrm{X} 2 \mathrm{Y}_{3}$ \\
\hline + Aphids and spiders & & $\mathrm{X} 2 \mathrm{Y} 2$ & $\mathrm{X} 2 \mathrm{Y} 2$ & & $\mathrm{X} 1 \mathrm{Y} 2$ \\
\hline \multicolumn{6}{|l|}{ Harmful diseases } \\
\hline + Leaf spots & X3Y3 & & & & \\
\hline + Root rot & $\mathrm{X} 2 \mathrm{Y} 2$ & $\mathrm{X} 2 \mathrm{Y3}$ & & $\mathrm{X} 1 \mathrm{Y} 1$ & \\
\hline + Rusts & & & & & $\mathrm{X} 1 \mathrm{Y} 1$ \\
\hline + Fungi (downy mildew fungi and leaf fungi) & & X3Y3 & $\mathrm{X} 2 \mathrm{Y} 1$ & $\mathrm{X} 1 \mathrm{Y} 1$ & $\mathrm{X} 2 \mathrm{Y} 1$ \\
\hline + Anthracnose and leaf yellowing & & $\mathrm{X} 2 \mathrm{Y} 2$ & & & $\mathrm{X} 1 \mathrm{Y} 1$ \\
\hline
\end{tabular}

Note: $X$ (popularity level); $Y$ (seriousness level); 1 (low); 2 (medium); and 3 (high). 


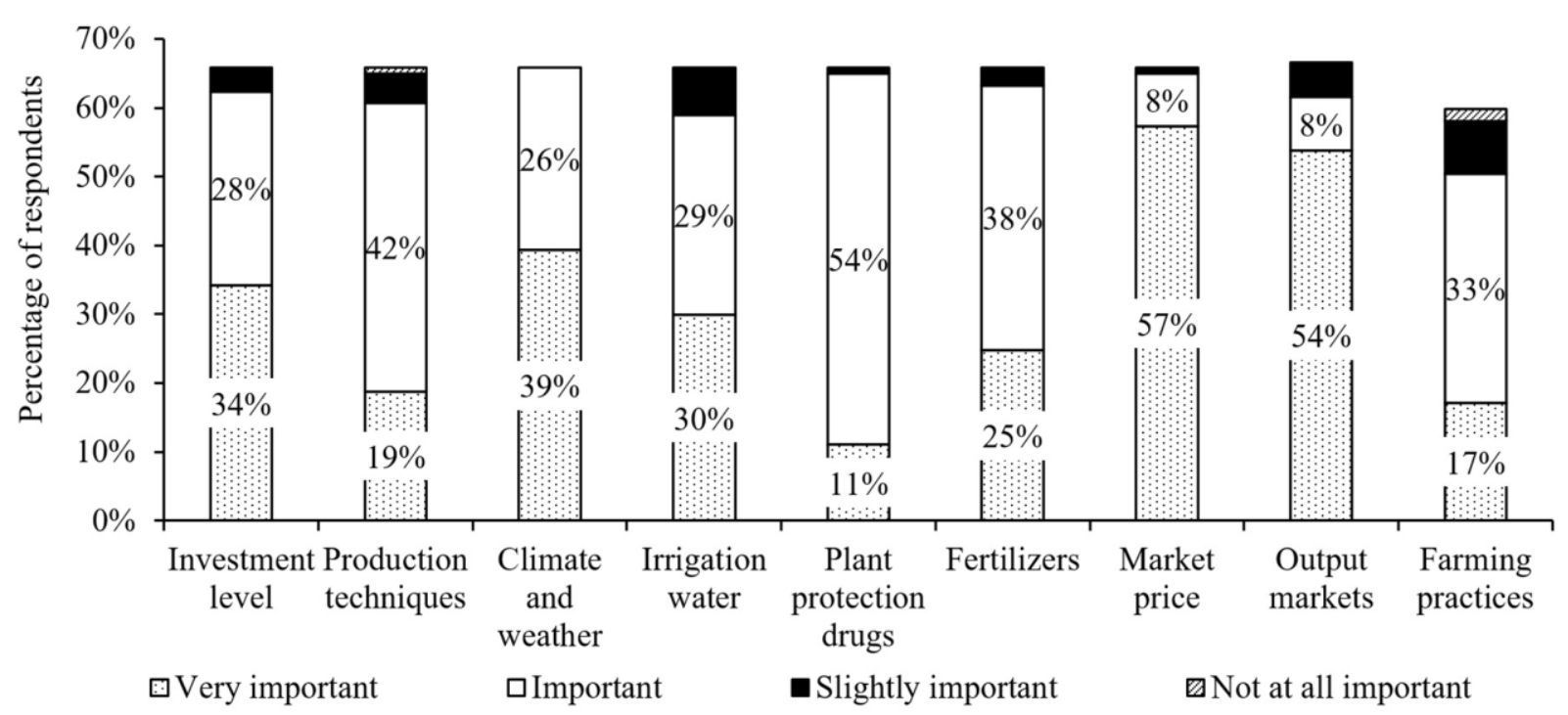

Figure 2. The importance of factors affecting vegetable and flower production and business

household producers were supported by the local government with new production technologies. However, most producers did not receive any financial supports, post-harvest technologies, or market access, and brand development. Even though Lam Dong was famous and more developed for flower and vegetable production, new market access and brand development had not been paid much attention by the local government. The solutions for promoting flower and vegetable exports were inefficient.

\section{Advantages and difficulties in the development of vegetables and flowers in the Central Highlands}

\section{Advantages and strengths}

First, the farmers/producers had a lot of experience in vegetable and flower production and pest/disease management or control, especially in Lam Dong. Some producers began to use new varieties, improve farming techniques, and apply advanced technologies in producing and post-harvesting such crops.

Second, local authorities played active roles in training farmers on safe vegetable production such as pesticide use and raising awareness of farmers in safe agricultural production.

Third, businesses, especially in Lam Dong, played an increasingly important role not only in market and brand development but also in introducing and supporting households to access new technologies in the production and preservation of agricultural products.

\section{Difficulties and challenges}

The majority of vegetable and flower producers, except for some large-scale farmers in Lam Dong, were highly dependent on weather conditions in crop production because they could not afford to invest in net houses or greenhouses. These were big challenges in flower and vegetable production when environmental pollution and climate change had negative impacts on agricultural production. For instance, ensuring irrigation water was a serious problem facing many flower and vegetable producers in the Central Highlands. In addition, produce damages caused by simple packaging and traditional shipping by rudimentary vehicles needed to be paid more attention to.

Most producers were unable to apply advanced technology in flower and vegetable production. The majority of these households watered their crops by hands and employed fertilizer broadcast method in their production. They were also unable to apply flowering treatments, except for those in Lam Dong, which could reduce the yield of flowers. In addition, most producers could not produce and preserve seeds for the following crops. Consequently, most of them had to buy seeds imported from foreign countries (about 80\%). Post-harvest technology was very limited, which could cause 
significant losses in agricultural products. Consumption of vegetables was mainly in fresh forms with low added value, while very few products were processed by modern technology.

Despite accumulating rich experiences in flower and vegetable production as mentioned above, household producers still faced a growing number of pests and diseases, especially those in Dak Lak, Dak Nong, and Gia Lai.

While Dak Lak and Dak Nong had relatively large areas of vegetable production, the yield was the lowest in the region. This raised the question of where the reasons came from. It might be due to unfavorable weather conditions, unsuitable soil, or poor farming techniques.

Finally, the biggest challenge faced by vegetable growers, based on their selfassessment, was the output market for such products. Currently, vegetables and flowers were mainly consumed domestically, in Ho Chi Minh city and neighboring provinces. The proportion of vegetables exported was very low. Unstable prices and oversupply or limited access to markets remained major barriers for producers on the way to expand their farm size. Meanwhile, the solutions for vegetable and flower market and brand development by local authorities have not been paid much attention nor adopted effectively.

\section{Discussion}

This study is one of the first to comprehensively assess the current situation of vegetable and flower production in terms of production land, yields, quantity, economic efficiencies, negative impacts of pests/diseases on such plants, and applications of technological advances at all five provinces of the Central Highlands of Vietnam. The findings provided significant policy recommendations and practical implications for both local governments and stakeholders in these sectors.

Some prior studies either focused on land use, water use (i.e., in coffee), or drought crisis in the Central Highlands (Minh, 2017; CCAFSSEA, 2016), while others only provided information on vegetables and/or flowers in a typical location such as Da Lat city, Lam Dong
(Bui Quang Tuan, 2016; Danse et al., 2007). The lack of a general evaluation limits recommendations policies and solutions for the development of vegetables and flowers in the whole Central Highlands. Our findings indicate that there was a significant difference in the production area, yields, and economic efficiency among the five provinces of the Central Highlands. Vegetables were mainly grown in Lam Dong, Dak Lak, and Gia Lai provinces, but the farmers in Lam Dong achieved the highest yield and economic efficiency. In other words, vegetables and flowers were the most economically produced in Lam Dong province, which is similar to several reports (Bui Quang Tuan, 2016; Danse et al., 2007). Meanwhile, the majority of flower areas were in Lam Dong province, others' accounted for very minor. This implies that vegetable and flower producers in other provinces should pay more attention to improving the yields and economic values of these crops.

Other scholars introduced the overall development of vegetables in Vietnam nationwide, but only placed an emphasis on the Red River Delta (i.e., Hanoi city) (Huong et al., 2013, Ngo et al., 2019). Besides that, these existing works did not evaluate the negative impacts of insects and diseases on the growth of vegetables and flowers (Bui Quang Tuan, 2016; Huong et al., 2013; Ngo et al., 2019). In this study, we identified the popularity and harmful seriousness of insects and diseases on vegetable and flower production across five provinces in the Central Highlands. Therefore, both producers and technical training provided by local government agencies are suggested to efficiently monitor and evaluate these negative effects on such crops caused by these insects and diseases. Moreover, little is known about growing techniques and technological advances that the farmers and producers applied in vegetable and flower production in this region. Our results revealed that these crop producers remained limited in applying modern water irrigation, flowering treatments, crop breeding, and postharvest preservation technology, except for a few big producers in Lam Dong. This may explain why many producers attained low yields and economic values. 
In addition to assessing the production and economic efficiency of flower and vegetable production in the Central Highlands, this work has found the most difficulties facing the producers and farmers, which has not been pointed out by previous work. Specifically, output market issues (i.e., fluctuations in market prices and instability in output markets) were the most barriers and most concerns to the farmers in the areas. This is consistent with what has been found in previous study of Ngo et al. (2019) which was conducted in Hanoi city in the North of Vietnam. Thus, essential solutions for improving the ability to access new domestic and export markets that need to be concentrated on include building brands of high-value vegetables and flowers or improving product quality through modern technological advances. These solutions were also recommended by prior work/reports (Decision No. 936 of the Prime Minister, 2012; JICA, 2017). Apart from market factors, the negative impact of climate change (i.e., drought) was also a big challenge for plant growers, which is in accordance with other findings reported by Bui Quang Tuan (2016) and Thai (2018). The upgradation of the irrigation system for such crops is needed as $70 \%$ of cultivation areas experienced severe drought (CCAFS-SEA, 2016).

This study found that vegetable and flower production played important roles in improving the likelihood of the Central Highlands' people, especially in Lam Dong province as suggested by previous scholars (Bui Quang Tuan, 2016; Danse et al., 2007). However, many challenges hinder the development of this area such as the negative impacts of climate change, deforestation, and natural depletion, which is similar to a recent report by Thai (2018). To solve this problem, it requires a comprehensive evaluation of the current situation of agricultural production in relation to climate change that is rapidly increasing in the region.

Based on the above findings, we propose policy recommendations to promote the development of the flower and vegetable industry in the Central Highlands region as follows: First, producers need to improve the yields of vegetables in the areas (i.e., Dak Lak and Dak Nong) where current yields remain much lower compared to those in Lam Dong province. The yield improvement can be done through technical training activities and the application of new seed varieties and modern technologies. Second, the supply of irrigation water for vegetable production is very important, which requires the participation and support of the local government as well as cooperations and benefit-sharing among vegetable/flower producers and businesses. Third, the local governments should support private stakeholders in building and developing brands of high-value flowers and vegetables. Fourth, it is crucial to expand markets for high-value flower and vegetable products through trade promotion activities and providing market information more widely to producers and businesses. Fifth, support policies for credit, innovating breeding technologies, and post-harvest preservation should be implemented more efficiently. These policies require close cooperation among all stakeholders (local government, producers, businesses, and research institutions) in the vegetable and flower supply chains in the Central Highlands.

Nevertheless, this study still has some main limitations. First, deep analyses of the main types of flowers and vegetables in each province have not been addressed, which limits to propose specific solutions for major crops in the Central Highlands. Second, surveys of other stakeholders in the supply chain of flowers and vegetables such as processors, retailers, and consumers are missing. Finally, factors affecting economic efficiency and the application of production technology based on quantitative methods or econometric models remain absent. Thus, further research should be focused on exploring factors affecting the development of main flower and vegetable varieties in terms of economic and technical aspects through surveying all the supply chain actors.

\section{Conclusions}

Overall, the development of vegetables and flowers in the Central Highlands' provinces has brought many economic benefits to producers, 
especially in Lam Dong province. However, the growers in this area have also been facing many difficulties and challenges in both production and consumption. Production technology and technological advances for vegetable production remain limited in terms of water and fertilizer application systems, seed breeding techniques, and post-harvest preservation. Despite that, the biggest problems perceived by producers are the output market and price instability. In addition, the negative impact of climate change (i.e., drought), soil degradation, and the shortage of water sources for plant cultivation are also big obstacles for vegetable and flower production in the region.

\section{Acknowledgments}

This study was financially supported by the Vietnamese government for the National project Applied Research for Technology Development (Reference Number: 02/KHCN- DTDL.CN18/18). The authors would like to acknowledge the help of the local leaders, officials, businesses, and farmers in the five surveyed provinces (including Dak Lak, Dak Nong, Gia Lai, Kon Tum, and Lam Dong) in the Central Highlands of Vietnam.

\section{References}

CCAFS-SEA (2016). The drought crisis in the Central Highlands of Vietnam. Assessment Report. Retrieved from https://core.ac.uk/download/pdf/132684728.pdf on May 25, 2020.

Dak Lak Statistics Office (2018). Dak Lak Statistical Yearbook 2017. Statistical Publishing House, Hanoi (in Vietnamese).

Dak Nong Statistics Office (2018). Dak Nong Statistical Yearbook 2017. Statistical Publishing House, Hanoi (in Vietnamese).

Danse M. G., Victoria N. G., Peeters F., Huong T. M. \& Luyen, C. H. (2007). Report on Fieldwork for 'Sustainable Flowers in Vietnam', Part Two, Dalat. Retrieved from https://library.wur.nl/WebQuery/wurpubs/fulltext/185 98 on May 25, 2020.

Department of Agriculture and Rural Development of Lam Dong province (2017). Report on the situation of production, consumption and development orientation of fruits and vegetables in Lam Dong province (in Vietnamese).
Do H. T. T., Grant J. C., Trinh B. N., Zimmer H. C. \& Nichols J. D. (2017). Diversity depends on scale in the forests of the Central Highlands of Vietnam. Journal of Asia-Pacific Biodiversity. 10(4): 472-488.

FAOSTAT (2019) Database about Vietnam agriculture. Retrieved from www.fao.org/faostat/en/\#country/237 on December 20, 2020.

Gia Lai Statistics Office (2018). Gia Lai Statistical Yearbook 2017. Statistical Publishing House, Hanoi (in Vietnamese).

Ha Anh (2016). Developing flower industry and ornamental plants in economic integration. Retrieved from https://dangcongsan.vn/kinh-te-va-hoinhap/phat-trien-nganh-cong-nghiep-hoa-cay-canhtrong-kinh-te-hoi-nhap-371659.html on December 20, 2020 (in Vietnamese).

Huong P. T. T., Everaarts A. P., Neeteson J. J. \& Struik P. C. (2013). Vegetable production in the Red River Delta of Vietnam. I. Opportunities and constraints. NJAS Wageningen Journal of Life Sciences. 67: 27-36.

Quang Huy (2017). Central Highlands Steering Committee: Annual average economic growth of over $10 \%$. Retrieved from https://bnews.vn/ban-chi-dao-taynguyen-tang-truong-kinh-te-binh-quan-hang-nam-dattren-10-/51127.html on June 1, 2020 (in Vietnamese).

JICA (2017). Data collection survey for formulating branding and promotion strategy of agricultural products and agro-tourism in Lam Dong province. Final Report. Retrieved from https://openjicareport.jica.go.jp/pdf/12286944.pdf on June 1, 2020.

Kon Tum Statistics Office (2018). Kon Tum Statistical Yearbook 2017. Statistical Publishing House, Hanoi (in Vietnamese).

Nguyen Khoi (2015). The Central Highlands Program 3 interdisciplinary integrated science and technology program. Retrieved from www.nhandan.com.vn/khoahoccongnghe/item/28314702-tay-nguyen-3---chuongtrinh-khoa-hoc-va-cong-nghe-tong-hop-liennganh.html on December 10, 2019 (in Vietnamese).

Lam Dong Statistics Office (2018). Lam Dong Statistical Yearbook 2017. Statistical Publishing House, Hanoi (in Vietnamese).

Lamdongdost (2016). How Da Lat flower brand becomes strong? Retrieved from http://lamdongdost.gov.vn/home/san-pham-dactrung/Hoa-da-lat/type/detail/id/1008 on December 20, 2020 (in Vietnamese).

Lamdongtv (2016). Export proportion of cut flowers in Da Lat remains low. Retrieved from http://lamdongtv.vn/tin-tuc-n796/cat-tien-dien-tichsan-xuat-lua-chat-luong-cao-dat-hon-7500-ha.html on September 10, 2020 (in Vietnamese).

Nguyen Cong Ly (2017). The socio-economic status of the Central Highlands has developed rapidly and comprehensively. Retrieved from 
www.nhandan.com.vn/chinhtri/item/31794502-kinhte-xa-hoi-vung-tay-nguyen-phat-trien-nhanh-va-toandien.html on December 12, 2019 (in Vietnamese).

MARD (2009). Manual of agricultural land use, volume 2. Science and Technique Publishing House, Hanoi (in Vietnamese).

MPI (2017). Synthetical report of the adjustment of the Master Plan for socio-economic development in the Central Highlands region to adapt to climate change. Retrieved from http://skhdt.gialai.gov.vn/getattachment/a6401e391034-4a2e-9119-86ff48b69edd/BCTH-QH-TayNguyen-3-5-2017-(in-xin-y-kien-Bo,-nganh).pdf.aspx on December 15, 2019 (in Vietnamese).

Ngo H. M., Vu H. Q., Liu R., Moritaka M. \& Fukuda S. (2019). Challenges for the Development of Safe Vegetables in Vietnam: An Insight into the Supply Chains in Hanoi city. Journal of Faculty of Agriculture, Kyushu University. 64(2): 355-365.

People Committe of Dak Lak province (2018). Report on the results of socio-economic development plan in 2017 and implementing plan for 2018.

Plant Protection Bureau of Lam Dong (2016). Assessing the current situation of developing safe vegetable production from 2005 to 2015 and directions and solutions for developing safe vegetables in Lam Dong province in the 2016-2020 period (in Vietnamese).

Decision No. 936 of the Prime Minister (2012). Approving of the Master Plan on Socio-Economic Development of the Central Highlands up to 2020 (in Vietnamese).

Bui Quang Tuan (2016). Economic restruturing of the Central Highlands toward sustainable development. Social Sciences Publishing House, Hanoi (in Vietnamese).

Thai H. A. C. (2018). Livelihood Pathways of Indigenous People in Vietnam's Central Highlands: Exploring Land-Use Change. Advances in Asian HumanEnvironmental Research. Springer International Publishing.

Van Hoi P., Mol A. P. \& Oosterveer P. J. (2009). Market governance for safe food in developing countries: The case of low-pesticide vegetables in Vietnam. Journal of Environmental Management. 91(2): 380-388

World Bank (2017). Vietnam Food Safety Risk Management - Challenges and Opportunities. Publishing and Knowledge Division. The World Bank, 1818 H Street NW, Washington, DC 20433, USA: $28-34$. 